\title{
A Comment on Terminology
}

My decision to employ two constructs - namely, "Indigenous Peoples" and "religion" - requires some attention before we begin. While my decision to use the category of "Indigenous Peoples" throughout this book - rather than the constitutional category of "Aboriginal Peoples" or the legal category of "Indian" (also enshrined in the Constitution) - likely requires no explanation, a comment on some complications around the term are necessary. The use of a singular, homogeneous label can have serious ramifications. The adoption of singularities can obscure and even eradicate the diversity of the many Original Peoples of Turtle Island that now fall under its banner. Recognizing Indigenous world views means recognizing the myriad of world views that exist from community to community. This is not to say that world views between communities are necessarily incommensurable, just that sameness should not be the starting point.

Reflecting on a study of Lakota/Dakota metaphysics from an Ojibwa perspective, Dennis H. MacPherson and J. Douglas Rabb assert, "We should not be looking for networks of inferential associations between Lakota and Ojibwa concepts. Any such inferential associations between Lakota and Ojibwa concepts would likely be imposed by the investigator." ${ }^{11}$ MacPherson and Rabb complicate this position by acknowledging that Indigenous Peoples did not exist in isolation but, rather, in relationship with other communities. These relationships sometimes involved the movement of peoples along with their specific cultures. ${ }^{2}$ Thus, MacPherson and 
Rabb call attention to both the diversity and interconnectedness of communities of Indigenous Peoples.

This reality of diversity and movement can pose problems when considered through the homogenizing lens of colonialism. A problem arises when difficult differences are dismissed and favourable world views are held as normative. This is certainly true with Gustafsen Lake - a case that occupies an entire chapter of this book - but it is also evident in other cases such as Cameron v. Ministry of Energy and Mines, where multiple communities held vastly different views on the drilling site in question. It is clear that the state often views difference with suspicion, privileging perspectives most compatible with the state position.

The claim that there is diversity among Indigenous Peoples, even at times within a community, is far from controversial in Indigenous studies and the subject-field of religious studies, despite noticeable complications in the courts. However, the claim that Indigenous Peoples hold something in common from community to community may be met with greater scepticism for good reason. Assertions of universalisms across all Indigenous Peoples risk homogenization. On this, I turn to Lakota philosopher Vine Deloria Jr, Apache philosopher Viola Cordova, and Anishinaabe political philosopher Dale Turner, all of whom contend that there is an underlying world view discernible among Indigenous Peoples. ${ }^{3}$ These Indigenous philosophers do not discount the unique cultural traditions of their own communities and others; rather, they speak to underlying general distinctions that separate Indigenous metaphysics from European perspectives. For example, one of the most critical distinctions identified by Deloria, Cordoba, and Turner is the land-person relationship. This distinction is affirmed in the Report of the Royal Commission on Aboriginal Peoples. The Commission writes, "To non-Aboriginal people and governments, the many millions of unfarmed, undeveloped hectares of Canada were 'Crown land,' public land their land. To Aboriginal people, land belonged only to the Creator, but by virtue of their role as stewards, it was theirs to care for, to use - and to share if they chose. ${ }^{\prime 4}$ In this sense, there is something that is shared across all Indigenous Peoples - distinct 
from European heritage - that provides a common feature of distinct cultural perspectives.

We should not think of the differences and commonalities between different communities under the banner of "Indigenous" as mutually exclusive locales of identity and world view. Just as culture was transmitted between communities historically, as noted by MacPherson and Rabb, the same sorts of transmissions take place on the global level today. Those who have embraced the more global identity of "Indigenous" have been influential in and influenced by that collective identity. This relationship between the local and the global, and how it is negotiated, is a resonating theme throughout Greg Johnson and Siv Ellen Kraft's edited volume, Handbook of Indigenous Religion(s). Johnson and Kraft write, "Indigeneity is a discursive and performative repertoire that has myriad authors (indigenous and not), stratum upon stratum of multiple-source sediment, unpredictable sympathisers and antagonists, uneven histories, and starkly consequential if wildly diverse legal ramifications. ${ }^{15}$ Johnson and Kraft explain that some communities may "draw upon and enhance their ... identities when translating their core values and traits for indigenous others in global forums; the common ground they find in doing so is then articulated back into the local spaces from which it emerged." ${ }^{\prime 6}$ At no point do I intend on marginalizing or dismissing the unique traditions of each community identified in this book. At the same time, I acknowledge that the relationship between the cultures of communities, internally and externally at local and global levels, is complex.

There has been a tendency to use the word "spirituality" when referring to Indigenous religious traditions. There is good reason for this, as the category of "religion" has been used as a tool of colonialism and oppression. Sociologically, there is no consensus on how these terms ought to be defined. It would appear that spirituality denotes a more personal and experiential phenomenon, whereas religion refers to institutions with formalized rituals and dogma. ${ }^{7}$ If this is how "religion" is understood, then it is inappropriate for Indigenous spiritual traditions. ${ }^{8}$ Many practitioners, including Splitting the Sky - interviewed for this book - reject the 
term "religion" in favour of spirituality. Complicating matters further is that spirituality, generally, may also be inadequate. In their literature review on resilience and Indigenous spiritualities, Joan Fleming and Robert Ledogar write, "Spirituality is closely bound up with culture and ways of living in Indigenous communities and requires a more holistic or comprehensive ... approach." ${ }^{\prime 9}$ Stepping beyond the spiritual-religious dichotomy, matters are complicated even further when we acknowledge that many Indigenous language systems do not possess adequate or equivalent terms for what "religion" has come to represent. ${ }^{10}$

The distinction between "Indigenous religion" and "Indigenous spirituality" is important for practitioners and for scholars, but it is of less consequence here. ${ }^{11}$ Canada's courts are not concerned with the distinctions between these two constructs. The decision in Syndicat Northcrest $v$. Amselem very clearly defines religion in terms removed from institutional orthodoxy, which is often associated with "religion." ${ }^{12}$ Anishinaabe legal scholar John Borrows succinctly addresses this complication in the context of the law. He writes, "Most Anishinabek spiritual expression differs substantially from what many people regard as religious ... Fortunately, definitions of the religious nature of Anishinabek spiritual beliefs may not prove fatal to their claims." He continues, "The Charter's standard for finding that a belief is religious is a 'nexus' with the divine or spiritual. This requirement is fortunately judged by subjective standards, meaning that a person's own declarations are seemingly sufficient to meet this test." ${ }^{13}$ In the most recent decision before the Supreme Court of Canada, the Ktunaxa Nation employed the term "spiritual." The court agree to use the term, though the court noted it still constituted a religion in the context of the law. ${ }^{14}$ Therefore, I employ the term "Indigenous religions" throughout this book with the recognition that beyond the law, the conversation is mired in complexity.

Readers will notice that I do tend to conflate the terms "religion" and "culture" in the pages that follow. Certainly religion and culture are intimately tied together, and the idea that religion can be distilled and separated from politics, economy, law, and even culture is part of the processes of the secular state that seeks to 
categorize and differentiate different aspects of human existence. ${ }^{15}$ Lori Beaman reminds us that "religion is separated out [from culture] as an analytical and lived category both in law and in public discourse at certain times and for certain purposes" and it is important to understand why such distinctions are made. ${ }^{16}$ For example, Beaman explains that Sunday closing laws may be viewed as cultural rather than religious and therefore protected. ${ }^{17}$ As for minority cultures, Beaman contends that "a hijab can ... be imagined as culturally specific (but not 'ours') and therefore not really religion and, consequently, not eligible for protection under religious freedom provisions." ${ }^{18}$ Michael McNally points to the dangers of translating religion into culture in legal frameworks, claiming such activities help to "re-inscribe and maybe even extend the reductive logic of the Enlightenment even as it seems to move beyond the religious/secular divide." ${ }^{19}$ While a more detailed investigation of the discourse surrounding the relationship between religion and culture is beyond the scope of this book, it is important to maintain an awareness of such tensions. As I will demonstrate, the courts understand Indigenous culture and religion to be bound together under section 35(1) cultural rights. For this reason, I tend to move between the two terms freely with an awareness of the complexity of the relationship between these concepts. 
